\title{
Pääkirjoitus: Millaista tutkimustietoa päätöksentekoon?
}

\author{
Ville-Pekka Sorsa, päätoimittaja
}

Keskustelu tutkimuksen ja päätöksenteon suhteesta on jatkunut aktiivisena koko kuluneen vuoden ajan. Viimeisen vuoden aikana keskustelua tutkimustiedon integroinnista päätöksentekoon on käyty median ohella niin tutkijoiden parissa (esim. Wass ym. 2017), eduskunnassa (esim. Jakonen 2017) kuin julkishallinnonkin piirissä (esim. Tuomisto ym. 2017). Myös esimerkiksi kotimaisessa tiedejulkisuudessa on nähty ja kuultu useita tutkimus- ja evidenssiperustaisen päätöksenteon tärkeyttä korostavaa puheenvuoroa (esim. Pekkarinen 2017).

Viime numerossa kritisoin puhetta totuudenjälkeisestä ajasta ja erityisesti ajatusta, jonka mukaan päätöksenteko voitaisiin perustaa pelkille faktoille (Sorsa 2016). Keskustelu tutkimuksen ja päätöksenteon suhteesta on kehittynyt vuoden aikana jonkin verran hedelmällisempään suuntaan. Tiedon ja muiden tekijöiden, kuten tunteiden tai ideoiden, suhde ymmärretään nyt luultavasti paremmin kuin vuosi sitten. Julkisesta keskustelusta paistaa kuitenkin edelleen läpi muutamia suuria ongelmia, minkä vuoksi päätin palata tiedon ja politiikan suhteen teeman myös tämän numeron pääkirjoituksessa. Monissa puheenvuoroissa kaikuu nimittäin naiivi retoriikka, jonka mukaan jossain tuolla tieteen uumenissa makaa se paras tieto, joka viranomaisten ja poliitikkojen pitäisi osata omaksua parhaiden politiikkavaihtoehtojen valitsemiseksi.

Tällaiset odotukset johtavat helposti pettymykseen. Ensimmäisen pettymyksen tuottaa jo se, ettei mitään neutraalia tai "objektiivisesti parasta" tietoa ole olemassa, jos tieto on lähtökohtaisesti mukana poliittisessa päätöksenteossa (Jakonen 2017). Ihmistieteiden normatiiviset ulottuvuudet ja poliittiset lataukset korostuvat aina, jos tiedon käyttöön sisältyy huomattavaa valtaa tai jos tiedon käyttöön liittyy monia intressejä. Yhdessä kohdassa päätöksentekoa se hyödyllisin tai neutraaleimmalta vaikuttava tieto saattaa näyttää toisessa 
vaiheessa hyödyttömältä tai poliittisesti vahvasti latautuneelta. Parhaaksi esitetyn tiedon mukaiset päätökset eivät taas välttämättä näytä kenenkään silmissä toivottavilta tai edes relevanteilta.

Tämä näkyy hyvin esimerkiksi talouspolitiikassa. Kuten Jukka Pekkarinen (2017, 320-321) on todennut, ei talouspolitiikka ole luonteeltaan lineaarista päämäärien muodostamista ja keinojen valikointia tutkitun tiedon avulla, vaan moninainen prosessi, joka "heijastaa talouden kehitysvaihetta ja rakennetta, siinä vallitsevia poliittisia voimasuhteita ja -- eri eturyhmien painostusvoimaa”. Millaista ikinä tällaisessa päätöksenteossa esiintyvä tieto onkaan luonteeltaan, tulee se aina edustaneeksi joitain voimasuhteita ja edistäneeksi joitain intressejä.

Vielä suurempaan pettymykseen törmätään, kun asiaa tarkastellaan tiedon omaksumismahdollisuuksien näkökulmasta. Julkishallinnon kapasiteetti käsitellä tietoa kokonaisvaltaisesti on heikkoa kiitos tiedonkäsittelyn ja -tuotannon ulkoistamisen ja tämän aiheuttamien jatkuvuus- ja oppimisongelmien (Kuusela ja Ylönen 2013). Nykymuotoista puoluepolitiikkaa ja hallintoa vaivaavat ylipäätään ylikireät aikataulut ja tehokkuusvaatimukset.

Tällaisissa olosuhteissa evidenssiperusteinen politiikka muuttuu usein politiikkaperusteiseksi evidenssin valikoinniksi (Strassheim ja Kettunen 2014, ks. myös Sanderson 2011). Tämä tarkoittaa sitä, että tutkimusnäyttö valikoidaan tiedon sisällön kriittisen arvioinnin sijaan sen mukaan, mikä on päätöksenteon suhteen kulloinkin kätevintä, yksinkertaisinta ja parhaiten saatavilla olevaa. Vaatimukset omaksua huomattavasti aikaa ja laaja-alaista osaamista vaativa avoimuuteen ja deliberaatioon perustuvan tiedon ja päätöksenteon integrointitapa vaikuttavat tällaisissa olosuhteissa lähinnä epätoivoisilta.

Molemmat pettymykset ovat harmillisia. Edellinen on harmillinen siksi, että se paljastaa naiivin käsityksen tiedon luonteesta. Jälkimmäinen on taas harmillinen siksi, että se tuo esiin epärealistisen käsityksen julkishallinnon nykytilasta. Suurin ongelma näissä naiiveissa lähestymistavoissa on kuitenkin oletukset siitä, että tieto sijaitsisi jollakin tavalla päätöksenteon ulkopuolella (ja toisin päin) tai että tutkimustieto voitaisiin jollain tavalla kytkeä suoraan päätöksentekoon vain tutkimusta kunnolla läpikäymällä. Avaan molempia ongelmia seuraavaksi hieman tarkemmin. 
Politiikkaperusteinen evidenssin valikointi on ilmaus, jota käytetään tavallisesti pilkkaamaan päätöksentekijöitä valikoivasta tutkimustiedon käytöstä (esim. Marmot 2004). Tällöin tullaan pilkanneeksi päätöksentekoa usein myös aivan tarpeettomasti. Kaikkeen ihmisiä koskevaan vallankäyttöön kun kuuluu evidenssin valikointi.

Vallankäytön näkökulmasta katsottuna merkittävin tieto on luonteeltaan konstitutiivista. Kaikkeen päätöksentekoon tarvitaan jonkinlaista konstitutiivista tietoa. Kuten jo Foucault aikanaan toi esiin, vallan ja tiedon välillä on tiivis, erottamaton ja tosiaan ruokkiva suhde. Kaikki vallankäyttö perustuu jonkinlaiseen tietoon ja sen käyttämiseen. Vallankäyttö myös tuottaa tietoa ja muokkaa tiedontuotantoa edelleen omiin tarpeisiinsa.

Konstitutiivinen tieto ei ole relevanttia siksi, että se kuvaisi maailmaa tarkasti tai tarjoaisi sille parhaan selityksen jossain historiallisessa tilanteessa. Se on relevanttia siksi, että se tekee jonkinlaisen maailman tuottamisen mahdolliseksi. Konstitutiivinen tieto valikoi maailmasta vain joitain piirteitä, tulkitsee maailmaa vain joidenkin kehysten tai piirteiden kautta, tai sitten tuottaa ajatuksen kokonaan toisenlaisesta maailmasta. Konstitutiivinen tieto on tässä mielessä normatiivista: se osoittaa, minkä ja millainen tietäminen on vallankäytölle relevanttia, käyttökelpoista ja sopivaa.

Maailman, esimerkiksi yhteiskunnan "neutraali" kuvaaminen tulee mahdolliseksi vasta sen jälkeen, kun konstitutiivisen tiedon kuvaama yhteiskunta on jo tuotettu - tapahtui se sitten pakkokeinoin nopeasti tuotettujen instituutioiden tai ajatuksien vähittäisen, tietoisen tai tiedostamattoman muutoksen kautta - ja sitä ylläpitävät valtasuhteet tietämisen tapa mukaan lukien luonnollistettu. "Neutraaliin” konstitutiiviseen tietoon perustuva päätöksenteko on taas luonteeltaan konservatiivista: se uusintaa maailmaa, joka on rakennettu kyseisen tiedon varaan.

Otetaan esimerkiksi tilastotiede eli statistiikka, jota voidaan pitää väestön hallintaan massoina perustuvien valtioiden pääasiallisena konstitutiivisen tiedon muotona. Tilastotiede perustettiin ihmisiä hallitsevien valtioiden tarpeita varten. Tilastotieteen kyky kuvailla yhteiskuntaa tarkasti syntyi vasta sitä mukaa, kun massayhteiskunnan instituutioita luotiin. Mitä tarkemmaksi tilastotieto muuttui, sitä helpompi yhteiskuntaa oli jälleen hallita. Käsitys 
yhteiskunnasta massayhteiskuntana ja tilastot yhteiskunnan luontevana kuvaamistapana nousivat itsestäänselvyyden asemaan käsi kädessä. Tilastoihin perustuva päätöksenteko taas uusintaa maailmaa, jossa hallitsijat tekevät päätöksiä massojen käyttäytymistä koskien.

Poliittinen päätöksenteko ei ole tietenkään mitä tahansa vallankäyttöä. Poliittisuudessa on kyse yhteiskunnan kontingenssista eli karkeasti ilmaistuna siitä, että yhteiskunta voidaan aina päättää rakentaa jonkin eri (ideologisen, sosiaalisen, materiaalisen yms.) järjestyksen varaan, kunhan se vain sulkee ulos toimijoita ja tukahduttaa antagonismeja riittävästi yhteisen päämääränasettelun ja päätöksentekoon riittävän yhtenäisyyden eli politiikan mahdollistamiseksi. Mitään yhteiskuntajärjestystä ei voida tuottaa, ylläpitää tai organisoida ilman järjestystä mahdollistavaa tietoa. Tässä mielessä tieto ja politiikka kulkevat aina jossain määrin käsi kädessä. Edes politiikka itsessään ei ole mahdollista ilman jonkinlaista politiikkaa ja sen yhteiskunnallista asemaa konstituoivaa tietoa ja ymmärrystä.

Ilman konstitutiivisen tiedon valikointia politiikka muuttuu mahdottomaksi. Mikäli politiikassa nojataan kiistattomuudessaan triviaalia lähestyvään tietoon, ei tällöin luultavasti olla päättämässä yhtään mitään. Sama pätee haluttomuuteen omaksua päätöksien vaatimaa konstitutiivista tietoa. Otetaan esimerkiksi Sipilän hallituksen suhde perustuslakiin. Perustuslaillinen tieto on valtioneuvoston toiminnan kannalta konstitutiivista. Se ei kerro hallitukselle, minkä tekeminen on oikein tai väärin tai toivottavaa tai ei-toivottavaa, vaan minkä tekeminen hallituksena on tai ei ole mahdollista sen virallisen mandaatin mukaan. Tällaisen tiedon huomiotta jättäminen johtaa vallan käyttämättä jättämiseen. Sipilän hallitus onkin saanut huomata jo useampaan kertaan, ettei sen ajamia lakeja ole ollut mahdollisia toteuttaa heidän mandaattinsa puitteissa.

Tiedolle on eniten kysyntää poliittisen päätöksenteon parissa silloin, kun tietoa voidaan tulkita monilla eri tavoilla. Tästä voidaan nostaa esimerkiksi eduskunnan viimeaikainen päätös tuoda niin sanotut vahvat oluet kauppoihin. Päätöksen jakolinjoja ei voi ymmärtää ilman kaikille yhteistä arviota siitä, että päätös lisää alkoholin käyttöä - eri tahot vain tulkitsevat tilannetta eri tavalla. Yksille sama tieto edustaa markkinarakoa, toisille kansanterveyden heikentämistä, kolmansille hyvää tapaa siirtää kulutusta miedompiin juomiin ja neljänsille moraalin rappiota. Sama tieto motivoi intressitahoja lobbaamaan päätöksen puolesta (esim. kansainväliset panimot, joiden bulkkioluet 
ovat viisiprosenttisia) ja sitä vastaan (esim. terveysalan järjestöt ja uskonnolliset ryhmittymät). Kaikkiin tulkintoihin ja päätöksiin kuuluu kuitenkin sama tilastotieteen mahdollistama tiedonkappale.

Yksittäisen ideologisen tai intressiryhmän näkökulmasta tieto on hyödyllisintä silloin, kun normatiiviset lähtökohdat ja tulkinnat on piilotettu niin vahvasti tiedon taustaoletuksiin, ettei niitä voi enää erottaa jo luonnollistetusta tiedosta. Piilotettu normatiivisuus on itse asiassa tyypillistä nykyaikaiselle asiantuntijatiedolle. Asiantuntijatieto on luonteeltaan siinä mielessä teknistä, että kaikki keskeiset normatiiviset ja poliittiset lähtökohdat, tulkinnat ja arvostelmat ovat implisiittisiä ja taustaoletuksen asemassa. Ne ovat toisin sanoen piilotettu teknisten käsitteiden "mustiin laatikoihin". Tämän vuoksi asiantuntijoita pidetään harvoin vastuussa päätöksistä, vaikka heidän vaikutuksensa niihin olisi kiistaton (so. ilman asiantuntijoita päätöksenteko ei olisi ollut mahdollista). Asiantuntijoiden vapauttaminen vastuusta kuuluukin keskeisesti asiantuntijavallan luonteeseen.

Millaista nyky-yhteiskunnan hallinnan konstitutiivinen tieto sitten on? Koko nyky-yhteiskuntaa on kutsuttu tieteen ja teknologian tutkimuksen parissa teknis-tieteelliseksi kapitalismiksi (esim. Lyotard 1984, Sunder Rajan 2006). Kapitalismiksi siksi, että se perustuu hyvin vahvasti omistusoikeuksiin, työn ja pääoman erotteluun sekä lukuisiin näihin periaatteisiin nojaaviin instituutioihin. Teknis-luonnontieteelliseksi siksi, että yhteiskuntaa hallitaan juuri tietynlaisen asiantuntijatiedon varassa. Taloustiede esitetään Science as Culture -lehden tuoreessa erikoisnumerossa nykykapitalismin keskeisimmäksi konstitutiivisen asiantuntijatiedon lähteeksi. Erikoisnumeron toimittaja Birch (2017) kuvaa koko nykykapitalismia teknotaloudelliseksi kapitalismiksi taloustieteen vahvan aseman johdosta. Erikoisnumeron kirjoittajat peräänkuuluttavatkin taloustieteen "mustien laatikoiden" avaamista nykypolitiikan sisältöjen ymmärtämiseksi.

Avaamista myös riittää, koska taloustiede on vahvasti mallikeskeistä (ks. tässä numerossa Eranti 2017). Birch (emt.) nostaa esiin useita aiemmassa tutkimuksessa havaittuja esimerkkejä. Taloustiede usein esimerkiksi samastaa elintason ja elämänlaadun bruttokansantuotteen tasoon, ihmisten käyttäytymisen ja päätöksenteon yksilöiden väliseen kilpailuun, politiikan tehokkuuden edistämiseen (kustannus-hyöty-analyysin avulla) tai pääomaintensiiviset teknologiat innovaatioihin. Käytännössä tämä tarkoittaa sitä, että mikäli poliittinen 
päätöksenteko nojaa Birchin kuvaamiin taloustieteen "mustiin laatikkoihin", tullaan ajaneeksi talouskasvua elämänlaadun muiden tapojen kohentamisen sijaan, kilpailua esimerkiksi yhteistyön sijaan, taloudellista tehokkuutta esimerkiksi oikeudenmukaisuuden tai ekologisen kestävyyden sijaan tai investointeja jo kehitettyyn teknologiaan luovuuden ja uusien teknologioiden etsimisen sijaan.

Kaikki tämä on hyvin tarkoituksenmukaista, jos päämääränä on tuottaa ja ylläpitää kapitalistista yhteiskuntaa, jota hallitaan ylhäältäpäin teknokraattisesti. Mikäli lainsäätäjien tietoisena päämääränä on tuottaa tai ylläpitää markkinoiden muodossa hallittua yhteiskuntaa, on sen kuunneltava sellaisia asiantuntijoita, jotka kykenevät näyttämään, miten ihmisten toiminta voidaan hahmottaa ikään kuin markkinoina ja hallita ihmisiä massoina markkinoihin liittyvien kannustimien avulla. Valtavirtainen mikrotaloustiede tuottaa juuri tällaista tietoa, jonka avulla ihmisiä saadaan ohjattua kuin rottia labyrintissa, toisin kuin esimerkiksi organisaatiopsykologia tai kulttuurintutkimus. Jälkimmäiset ovat tarpeellisia, mikäli ihmisiä pyritään hallitsemaan heidän motivaationsa tai heidän omaksumiensa normien ja uskomusten välityksellä muuten kuin valintoja tekevinä massoina.

Politiikkaperusteisen evidenssin termin käyttäminen pilkkakirveenä vaikuttaa edellä sanotun perusteella hölmönä, koska kaiken politiikan lähtökohtana on jonkinlainen evidenssin valikointi - jostain tiedosta tehdään aina konstitutiivista ja toisesta ei. Vaikuttaa siltä, että evidenssiperusteista päätöksentekoa peräänkuuluttavat äänekkäimmin julkisuudessa lähinnä sellaiset tahot, jotka haluavat päätökset sekä tehtävän että oikeutettavan jonkin heidän preferoimansa asiantuntijatiedon lajin ja sen "oikeiden" tulkintojen kautta. Tällaiset puheenvuorot tulee lukea tavallisina hegemoniakamppailuina, joissa rinnastetaan oma asiantuntijatieto retorisesti kaikkeen asiantuntijatietoon.

Toki politiikkaperusteisen evidenssin termi sisältää myös kohdallisen huomion. Tehtäviä päätöksiä joskus oikeutetaan vetoamalla päätösten tekemisen kannalta kokonaan irrelevanttiin eli ei-konstitutiiviseen tietoon. Tällaiseen on tietysti aina syytä puuttua, varsinkin silloin, jos oikeutuksessa ja päätöksessä käytetty tieto on keskenään ristiriitaista. Rehellinen päätöksentekijä oikeuttaa päätökset sillä tiedolla, jota päätöksessä on käytetty. Tämä ei kuitenkaan tarkoita sitä, että tiedon täytyisi olla jollakin tavalla tieteellisesti hyväksyttyä. Tiedon tieteellinen luotettavuus on toissijainen huolenaihe, 
jos tiedosta voidaan tehdä todellisuutta. Normatiivinen sopivuus on tällöin merkittävämpi kysymys. Mikäli tiedon normatiivinen luonne ei sovi tehtyjen päätöksien tavoitteisiin, ei päätöksenteossa käytetty tieto epäilemättä ollut "parasta".

Mikäli yhteiskunnan halutaan perustuvan systemaattiselle tiedonkeruulle ja -tuotannolle, on yhteiskunnan päätetyssä rakenteessa (politiikka ja talous mukaan lukien) annettava jonkinlainen perustava asema juuri tutkimukselle muiden tiedontuotannon lajien mukaan. Mutta millainen rooli tutkimukselle voidaan antaa päätöksenteossa? Entä millaiselle tutkimukselle pitäisi antaa asema? Ja miten erilaisia tutkimuksia voidaan ylipäätään huomioida päätöksenteossa? Organisaatiotutkimuksen parista on noussut monia hedelmällisiä vastauksia näihin kysymyksiin. ${ }^{1}$

Romme (2003) on erotellut kolme erilaista tieteellisen tutkimuksen genreä ja näiden suhdetta organisointiin. Luonnontieteellisen tutkimuksen (science) lähtökohtana on tarkastella ennalta määriteltyjä ilmiötä ilmiöiden yleisten toimintojen ja niitä selittävien voimien kannalta niiden ulkopuolelta. Maailma nähdään havaittavina asioina ja tutkimus sitä vain katsovana toimintana. Tutkimuksen tarkoituksena on muodostaa kausaalisia selityssuhteita, testata hypoteeseja ja muodostaa näiden pohjalta universaaleja teorioita (tai "luonnonlakeja").

Ihmistieteellinen tutkimus (humanities) perustuu käsitykseen ihmisistä refleksiivisinä toimijoina, jotka voivat myös päättää omia "luonnonlakejaan". Sen lähtökohtana on tarkastella ilmiöitä niiden "sisältäpäin" eli ihmisten näkökulmasta - miltä asiat näyttävät, millaisia merkityksiä niillä on, miltä ne tuntuvat ja miten ne koetaan eri tilanteissa ja konteksteissa. Maailma nähdään diskursseina eli materiaalisina, sosiaalisina ja kielellisinä suhteina ja käytäntöinä. Tutkimuksen tarkoituksena on usein tulkita maailman eri piirteitä (esim. onko yhteiskunta oikeudenmukainen) sekä muodostaa kokonaiskuvia siitä, millä eri tavalla ihmiset näkevät ja ymmärtävät maailman.

Molemmat näistä genreistä ovat arvokkaita politiikan näkökulmasta, vaikka kumpaakaan niistä ei ole tarkoitettu siihen. Otetaan esimerkiksi hallinta motivoinnin keinoin. Luonnontieteellinen tieto on arvokasta ihmisten hallintaan 
näiden ulkoisen motivaation muokkaamisen keinoin, kun taas ihmistieteet ovat arvokkaita ihmisten sisäisen motivaation muokkaamisen kannalta. Kumpikaan motivaatiota koskeva tutkimuksen laji ei kuitenkaan kytkeydy suoraan päätöksentekoon. Tutkimus jättää poliittisten päätöksentekijöiden harteille kaiken alkaen sen pohdinnasta, missä määrin saatava tieto on ylipäänsä kytkettävissä politiikkatoimenpiteisiin.

Pohdittavaa myös riittää. Luonnontiede tulee päätöksentekoon lähinnä sen tuottamien teorioiden ja niiden muodostaman eräänlaisen työkalupakin kautta. Se ei kuitenkaan kerro, miten työkaluja pitäisi käyttää historiallisesti muuttuvissa tilanteissa, onko niiden käyttäminen toivottavaa tai ovatko työkalut tehokkaita, jos päätöksenteon kohteet tajuavat työkalujen olevan käytössä. Ihmistieteellinen tutkimus puolestaan voi näyttää, millainen haluttu maailma on luonteeltaan ja miten ihmiset siihen suhtautuvat sen tiedostaessaan. Koska ihmistieteellinen tieto on tavallisesti luonteeltaan kriittistä, eikä se tarjoa yksinkertaistettuja työkaluja, voi se näyttää päätöksentekijöiden näkökulmasta enemmän ongelmien kuin ratkaisujen lähteenä. Ongelmat on kuitenkin myös pakko tiedostaa. Kuka lainsäätäjä kannattaisi toimintaa, joka näyttäisi kaikkien hänen äänestäjiensä silmissä tuomittavalta?

Näiden ohella on myös kolmas tutkimuksen genre - muotoilutiede tai design - joka yhdistää tutkimuksen ja päätöksenteon jo lähtökohtaisesti. Tämän tutkimuksen genren eksplisiittisenä tavoitteena on tuottaa jotain, mitä ei vielä ole olemassa. Tutkimuksen perustana on ymmärrys siitä, että jokainen tilanne on ainutlaatuinen, eikä siitä voida esittää mitään yhtä universaalia luonnontieteellistä totuutta tai yleispätevää ihmistieteellistä tulkintaa. Tutkimus on siksi luonteeltaan pragmaattista ja ei-dogmaattista - maailman tuottaminen voi perustua mihin tahansa mekanismiin tai merkitykseen, kunhan se vain toimii. Mutta ennen kaikkea se vaatii uuden kuvittelua, toiminnan interventioita ja ongelmien ratkaisemista. Tutkimuksen tavoitteena on muodostaa jonkinlainen järjestelmä, joka kykenee ylläpitämään itseään, perustui järjestelmän logiikka sitten luonnontieteelliseen, ihmistieteelliseen tai kokonaan tutkimukseen perustumattomaan tietoon - pääasia, että ihmiset tekevät haluttuja asioita.

Erilaisilla tieteenaloilla on varsin erilaisia lähtökohtia näihin kolmeen genreen. Palataan valtavirtaisen taloustieteen esimerkkiin. Kuten Greg Mankiw (2006) on osuvasti todennut, toimivat taloustieteilijät maailmassa 
enemmän insinööreinä kuin luonnontieteilijöinä, vaikka esiintyvätkin mielellään juuri jälkimmäisinä (Mankiwin mukaan varsinkin makrotaloustieteen kohdalla usein myös varsin katteettomasti). Taloustieteen itseidentiteettiin kuuluu vahvasti ajatus taloustieteestä luonnon-, eikä ihmistieteellisenä tietona edellä kuvatussa mielessä. Identiteettiin kuuluu vahvasti myös se, että kieltäydytään ottamasta mitään vastuuta heidän päätöksenteon asiantuntijarooleistaan tai tuotetun tiedon pohjalta tehdyistä päätöksistä ikään kuin he olisivat päätöksenteosta riippumattomia luonnontieteilijöitä. (Fourcade ym. 2015.)

Luonnontieteellisessä mielessä mikrotaloustieteen panos päätöksentekoon on pysynyt oikeastaan muuttumattomana sitten 1700-luvun tai tarkemmin ottaen Jeremy Benthamin teorian siitä, että ihmiset preferoivat enemmän heitä miellyttäviä kuin ei-miellyttäviä asioita. Mikrotaloustieteen panos yhteiskuntaan on kuitenkin ollut valtava design-tutkimuksen mielessä: taloustieteilijät ovat kyenneet soveltamaan tätä ikivanhaa teoriaa lähes mihin tahansa tilanteeseen ja suunnittelemaan sen avulla kannustimia, joiden avulla ihmisiä on voitu hallita heidän halujensa ja markkinamekanismien välityksellä. Taloustiede on ollut kiistattomasti relevantein yhteiskuntatiede jo pitkään - ei siis siksi, että se kuvaisi maailmaa tarkimmin tai luotettavimmin, vaan siksi, että se on onnistunut niin vaikuttavasti muotoilemaan maailmaa oman designinsa mukaiseksi.

Design-tutkimus vaikuttaa poliittisen päätöksenteon kannalta hyvin lupaavalta tutkimuksen lajilta. Siihen sisältyy kuitenkin kaksi suurta muotoilun kestämättömyyteen liittyvää haastetta. Välittömin haaste on tiedon homogeenisuuden uhka. Mikäli design perustuu vain yhdenlaiseen tutkimuksen lajiin tai teoriaan, tönitään ihmisiä aina samalla tavalla ja jokaiseen ongelmaan saadaan aina sama ratkaisu. Jotta tämä toimisi, vaatii niin hallintakeinot kuin niiden taustalla oleva tiedontuotanto äärimmäisen korkeaa legitimiteettiä hallittavien parissa.

Esimerkiksi taloustieteelliseen maailmankuvaan nojaavat yhteiskunnan hallinnan mekanismit ovat viime vuosina nousseet merkittävän kritiikin kohteeksi (Welsh ja Wynne 2013), mikä on johtanut siihen, ettei ihmisiä pysytä hallitsemaan tehokkaasti rationaaliseen laskelmointiin vaikuttamalla. Vastaavasti esimerkiksi liike-elämässä johtamiskonsulttien tuottama loputon "bisnes-bullshit" on saanut osakseen runsaasti vastarintaa, mikä on tehnyt 
pelkkään kommunikaatioon ja motivointiin perustuvasta johtamisesta erittäin hankalaa (Spicer 2017).

Mikäli päätöksenteossa nojataan siis aina samojen "hovitutkijoiden" tai konsulttien ja heidän tietotyyppinsä varaan, päädytään nopeasti legitimiteettikriisin myötä kestämättömään muotoiluun. Samaan lopputulokseen päädytään usein myös toisesta syystä. Muotoilututkimuksen toinen merkittävä haaste onkin tendenssi pyrkiä niin kutsuttuun suljettuun muotoiluun (ks. Garud ym. 2008). Usein design-tutkimusta riivaa pyrkimys tuottaa yksi "lopullinen" järjestelmä sen sijaan, että nojattaisiin toiminnan jatkuvaan uudelleenmuotoiluun. Muotoilua täytyy uudistaa, jotta se kykenisi vastaamaan muuttuviin olosuhteisiin, ja sen täytyy perustua monipuoliseen ja jatkuvaan tiedonhankintaan, jotta olosuhteiden muutoksesta oltaisiin perillä. Yhteiskunnallisessa kontekstissa voisi helposti nostaa markkinateknokratiat tai suunnitelmataloudet esimerkeiksi tästä ongelmasta ja kuitata ongelman niillä. Mutta tällöin ongelmaa ei ole ymmärretty oikein - kyse ei ole mistään tietystä designista, vaan koko muotoiluprosessista. Kyse on siitä, ettei järjestelmän muuttujien muokkaaminen riitä, vaan koko järjestelmä pitää muotoilla koko ajan uudelleen.

Varsinkin poliittisen päätöksenteon näkökulmasta maailma on koko ajan muutoksessa. Jotta yhteiskunnan muotoilua voitaisiin toteuttaa avoimesti ja tehokkaasti, ei päätöksenteko voi nojata vain yhdenlaiseen, tarvittaessa hankittavaan tai yksittäisten ongelmien ratkaisuun tähtäävään tietoon, oli itse yhteiskunnan design millainen tahansa. Mikäli päätöksenteossa kuunnellaan aina vain yhdenlaisia tulkintoja tai yhdenlaista tiedekäsitystä edustavia ääniä tai sitoudutaan vain yhdenlaiseen yhteiskuntarakenteeseen (kuten markkinoihin tai osakeyhtiöihin), ei designissa pahimmillaan edes havaita ongelmia, vaikka koko järjestelmä olisi kaatumispisteessä.

Jos tutkimukseen perustuvaa päätöksentekoa halutaan edistää poliittisessa päätöksenteossa, ei se voi perustua pelkästään luonnontieteelliseen tai ihmistieteelliseen tutkimukseen, koska kytkentä päätöksentekoon jää väistämättä hyvin löyhäksi. Jotta päätöksenteko voisi perustua muotoilututkimukseen, vaatisi tämä äärimmäisen laajaa osaamispohjaa, monitieteellistä ajattelutapaa, huomattavaa yhteiskunnallista mielikuvitusta sekä kykyä muokata teorioista uusia käytäntöjä. Tarvitaan kokeellisia ja kehittäviä tutkimusasetelmia, ihmisten asenteita ja reaktioita kartoittavaa luotaamista, teoreettista ja empiiristä tietoa, 
huomiota rationaaliseen ja irrationaaliseen toimintaan sekä tieteellistä, ja ellei se riitä, niin taiteellista mielikuvitusta. Tämä vaatii toki vahvaa ja vapaata perustiedettä - niin luonnontieteellistä kuin ihmistieteellistäkin tutkimusta tuottamaan muotoiluun tarvittavia uusia päämääriä, työkalupakkeja, tulkintoja ja testaamistapoja. Mutta ennen kaikkea se vaatii kykyä soveltaa näitä ainutlaatuisissa historiallisissa tilanteissa.

Väitän, että Suomessa ei nykyisellään ole määritelty riittäviä resursseja muotoilututkimuksen edistämiseen päätöksenteossa. Liiallisen kiireen ja ydinosaamisen jatkuvan vuodon riivaamalla kotimaisella julkishallinnolla ei ole resursseja ylläpitää yhteiskunnan onnistuneeseen muotoiluun tarvittavia laajoja tutkimusresursseja - saati sitten aiempaa tietoa kumuloivaa tai edes tietoa ylläpitävää organisaatiomuistia. Puolueilla ei ole riittävästi kapasiteettia edes maailman hallintaan vaadittavan konstitutiivisen tiedon hankintaan, kuten istuva hallitus on osoittanut. Monille asiantuntijoille nämä seikat sopivat erinomaisesti, koska se tarkoittaa heille huomattavaa toimeentulon lähdettä. Hallitsevassa asemassa olevat asiantuntemuksen lajit puolestaan sopivat niille päätöksentekijöille ja intressitahoille, joiden ajaman politiikan nämä tiedon lajit mahdollistavat. Voidaan siis kysyä, löytyykö riittävän monipuolisen ja perusteellisen muotoilututkimuksen edistämiseen edes riittävää poliittista tahtoa.

Tilanne ei välttämättä ole sen parempi julkishallinnon ulkopuolella. Tutkimusrahoituksen silppuuntumisen kanssa kamppailevilla tutkimusryhmillä ja tutkimuslaitoksilla ei ole mahdollisuuksia tehdä korkealaatuista perus- ja muotoilututkimusta samanaikaiseksi. Monet yritykset ovat riippuvaisia julkisesta rahoituksesta edes jo olemassa olevan tutkimus- ja kehitystoiminnan ylläpidossa. Yliopistoilla on liian vähän perusrahoitusta. Varsinkin ihmistieteissä Suomessa työskentelee monilla aloilla vähemmän tutkijoita kuin muiden Pohjoismaiden yksittäisillä suuremmilla yliopistoilla.

Poliittinen asenneilmastokaan ei vaikuta suotuisalta muotoilututkimuksen resurssien kasvattamiseen. Pääministerit vähättelevät dosentteja ja tutkimustietoa julkisuudessa. Johtavissa asemassa olevat talouskeskustelijat nälvivät muita talouskeskusteluun osallistujia ikään kuin heillä tulisi olla monopoli 
julkisessa keskustelussa (ks. tässä numerossa Eskelinen ja Jonker-Hoffrén 2017). Tällaisilla hegemoniakamppailun aggressiivisilla muodoilla on myös seurauksensa. Tutkijoita uhkaillaan sosiaalisessa mediassa ja kansalaiset juottavat lapsilleen hopeavettä, koska meitähän eivät kaiken maailman dosentit määräile.

Tämä Poliittinen talous -lehden numero sisältää yhden alkuperäisartikkelin ja kaksi kirja-arvioita. Artikkeleita yhdistää suureksi osaksi asiantuntijuuden ja sen rakentumisen teemat.

Teppo Eskelinen ja Paul Jonker-Hoffrén tarkastelevat alkuperäisartikkelissaan kotimaisten taloustieteilijöiden asiantuntijayhteisön rakentamisen ja ylläpidon tapoja erityisesti sosiaalisessa mediassa. Tutkimus jatkaa episteemisten yhteisöjen kansainvälistä tutkimusta ja vahvistaa aiemmin englanninkielisestä mediasta havaittujen asiantuntijuuden rakennustapoja löytyvän myös kotimaisten taloustieteilijöiden piiristä. Artikkelin löydöksiä voidaan kuitenkin tulkita myös niin, että kotimaiset taloustieteilijät ovat omaksuneet sosiaalisessa mediassa portinvartijan roolia jopa koko julkisen talouskeskustelun suhteen. Tämän ilmiön luonnetta ja yleisyyttä olisi syytä tutkia paitsi tarkemmin myös laajemmin kansainvälisesti.

Veikko Eranti jatkaa taloustieteen asiantuntijuuden rakentumisen aihepiiriä omassa kirja-arviossaan. Dani Rodrik pohtii Erannin arvioimassa kirjassa taloustieteen vahvuuksia ja heikkouksia asiantuntijatiedon tuottajina. Rodrik lähestyy kysymyksiä hyvin yksilökohtaisesti. Hänen mukaansa taloustieteilijöiden suurin ongelma on siinä, ettei heitä ole koulutettu valikoimaan mallejaan maailman asettamien vaatimusten mukaan - toisin kuin muissa yhteiskuntatieteissä, Eranti huomauttaa - eikä kaikilla ole edes halukkuutta kehittää tätä kapasiteettia. Edellä sanotun perusteella tämä tarkoittaisi ei enempää eikä vähempää kuin sitä, ettei taloustieteilijöillä ole välttämättä kykyä ymmärtää oman tietonsa asemaa päätöksenteossa.

Maarit Laihonen tarkastelee kirja-arvoissaan kahta Talvivaaran kaivoksesta kirjoitettua teosta. Laihonen nostaa teoksista esiin kaksi varsin erilaista tarinaa: on Talvivaaran taloudellinen kertomus, jossa avainhenkilöt tekevät kaivoksella omaisuuksia, sekä nikkelintuotannon tekninen tarina, jolla ei näytä 
olevan paljoakaan tekemistä lainoin ja osakeannein kerätyn rahan kanssa. Laihosen mukaan teokset osoittavat, etteivät hankkeen avainhenkilöt itse asiassa rikastuneet niinkään kaivoksella, vaan siitä kerrotulla tarinalla. Tämä huomio on kiinnostava liiketoiminnan konstitutiivisen tiedon näkökulmasta: liiketoiminnan menestyksen kannalta voi olla tärkeämpää tuottaa tietoa itse yrityksen identiteetistä kuin sen konkreettisesta liiketoiminnasta.

\section{Viitteet}

I) Sivuhuomiona todettakoon, että organisaatiotutkimus on viimeisen noin kymmenen vuoden aikana kiinnittänyt aiempaa enemmän huomiota niin kutsuttuun osittaiseen organisointiin (partial organization), jossa päätetyltä järjestykseltä ei vaadita "kokonaisen" organisaation jokaista elementtiä eli jäsenyyttä, hierarkiaa, sääntöjä, valvontaa ja sanktiointia (ks. esim. Ahrne ja Brunsson 2011). Tämä on nostanut organisaatiotutkimuksen piiriin huomattavan määrän uusia ilmiöitä markkinoiden ja sosiaalisten liikkeiden kautta aina kansainvälisten instituutioiden ja ekosysteemien muotoiluun saakka. Tämä on tuonut organisaatiotutkimuksen varsin lähelle alkuperäistä "kokonaisvaltaista yhteiskuntatiedettä" eli poliittisen talouden tutkimusta (Heiskala ja Virtanen 2016). 


\section{Lähteet}

Ahrne, Göran ja Brunsson, Nils. 2011. Organization outside organizations: the significance of partial organization. Organization, 18:1, 83-104.

Eranti, Veikko. 2017. Kuinka riidellä taloustieteilijöiden kanssa? Poliittinen talous, 5:1.

Eskelinen, Teppo ja Jonker-Hoffrén, Paul. 2017. Taloustiede episteemisenä yhteisönä ja kamppailu asiantuntijuudesta. Poliittinen talous, 5:1.

Fourcade, Marion, Ollion, Etienne ja Algan, Yann. 2015. The Superiority of Economists. Journal of Economic Perspectives, 29:1, 89-114.

Garud, Raghu, Jain, Sanjay ja Tuertscher, Philipp. 2008. Incomplete by Design and Designing for Incompleteness. Organization Studies, 29:3, 351-371.

Heiskala, Risto ja Virtanen, Akseli. 2016. Esipuhe. Teoksessa Risto Heiskala ja Akseli Virtanen (toim.), Talous ja yhteiskuntateoria II: Modernin maailman talous ja sen kritiikki. Helsinki: Gaudeamus, 7-17.

Jakonen, Mikko. 2017. Vastatieto: tulevaisuuden asiantuntijuutta etsimässä.

Eduskunnan tulevaisuusvaliokunnan julkaisu No. 1/2017. Helsinki: Eduskunta.

Kuusela, Hanna ja Ylönen, Matti. 2013. Konsulttidemokratia: miten valtiosta tehdään tyhmä ja tehoton. Helsinki: Gaudeamus.

Lyotard, Jean-François. 1984. The Postmodern Condition. Manchester: Manchester University Press.

Mankiw, N. Gregory. 2006. The Macroeconomist as Scientist and Engineer. The Journal of Economic Perspectives, 20:4, 29-46.

Marmot, Michael G. 2004. Evidence based policy or policy based evidence? BMJ: British Medical Journal, 328:7445, 906-907.

Pekkarinen, Jukka. 2017. Taloustieteen ja talouspolitiikan vuorovaikutus:

Suomen erityispiirteitä. Kansantaloudellinen aikakauskirja, 113:3, 320-330.

Romme, A. Georges. L. 2003. Making a Difference: Organization as Design. Organization Science, 14:5, 558-573.

Sanderson, Ian. 2011. Evidence-based policy or policy-based evidence?

Reflections on Scottish experience. Evidence \& Policy: A Journal of Research, Debate and Practice, 7(1), 59-76.

Sorsa, Ville-Pekka. 2016. Pääkirjoitus: Emme koskaan ole olleet totuudenjälkeisiä. Poliittinen talous, 4:1. 
Spicer, Andre. 2017. Business Bullshit. New York, NY: Routledge.

Strassheim, Holger ja Kettunen, Pekka. 2014. When does evidence-based policy turn into policy-based evidence? Configurations, contexts and mechanisms. Evidence \& Policy: A Journal of Research, Debate and Practice, 10:2, 259-277.

Sunder Rajan, K. 2006. Biocapital. Durham: Duke University Press.

Tuomisto, Jouni, Muurinen, Raimo, Paavola, Juho-Matti, Asikainen, Arja, Ropponen, Teema ja Nissilä, Jussi. 2017. Tiedon sitominen päätöksentekoon. Valtioneuvoston selvitys- ja tutkimustoiminnan julkaisusarja No. 39/2017. Helsinki: Valtioneuvoston kanslia.

Wass, Hanna, Rinne, Jenni ja Koikkalainen, Petri. 2017. Korkeapainetta, huippuvirtauksia ja perustutkimusmailla hallan vaara. Politiikasta.fi. http:// politiikasta.fi/korkeapainetta-huippuvirtauksia-ja-perustutkimusmailla-hallanvaara/ [Luettu 14.12.2017]

Welsh, Ian ja Wynne, Brian. 2013. Science, scientism and imaginaries of publics in the UK: Passive objects, incipient threats. Science as Culture, 22:4, 540-566. 